\title{
Survey of Antibodies to Rift Valley Fever Virus and Associated Risk Factors in One-Humped Camels (Camelus dromedarius) Slaughtered in Maiduguri Abattoir, Borno State, Nigeria
}

Hassan Ismail Musa ( $\sim$ hassankwanda@gmail.com )

University of Maiduguri Faculty of Veterinary Medicine https://orcid.org/0000-0002-4471-3761

Caleb Ayuba Kudi

Ahmadu Bello University Faculty of Veterinary Medicine

Muhammad Mamman Gashua

University of Maiduguri Faculty of Veterinary Medicine

Abubakar Sadiq Muhammad

University of Maiduguri Faculty of Veterinary Medicine

Abdulyeken Olawale Tijjani

University of Maiduguri Faculty of Veterinary Medicine

Adamu Saidu Saleh

University of Maiduguri Faculty of Veterinary Medicine

Sani Mohammed

University of Maiduguri Faculty of Veterinary Medicine

Saleh Mohammed Jajere

University of Maiduguri Faculty of Veterinary Medicine

Shuaibu Gidado Adamu

University of Maiduguri Faculty of Science

\section{Research Article}

Keywords: Seroprevalence, Antibodies, Rift Valley Fever, One-humped camel, Abattoir

Posted Date: July 7th, 2021

DOI: https://doi.org/10.21203/rs.3.rs-651142/v1

License: (c) (i) This work is licensed under a Creative Commons Attribution 4.0 International License.

Read Full License 


\section{Abstract}

Rift Valley fever (RVF) is an emerging mosquito-borne zoonosis that threatens public health and animal agriculture in the endemic areas causing devastating epizootics characterized by abortion storms and high mortalities, especially in newborn animals. A cross-sectional study was conducted to determine the seroprevalence and investigate risk factors associated with exposure to the virus in camels slaughtered in Maiduguri abattoir, Borno state of Nigeria. Camels presented for slaughtered were sampled and data on age, sex, source or origin, utility, presence of post mortem lesions, body weights and body condition score were collected. Blood samples were collected and sera were harvested and stored at $-20^{\circ} \mathrm{C}$ until tested. The sera were tested using a commercial ELISA kit based on the manufacturer's instructions. The overall seroprevalence in the study was $20.7 \%(95 \% \mathrm{Cl}, 13.6$ - 30.0). The analysis showed no significant differences between presence of antibodies and variables that included the sex of camels $\left(c^{2}=0.015, \mathrm{df}=\right.$ $1, p=0.904)$ and presence of post mortem lesion on the carcass $\left(c^{2}=0.009, d f=1, p=0.925\right)$. There were significant differences between presence of antibodies and three variables that included the age $\left(c^{2}=\right.$ $4.89, \mathrm{df}=1, \mathrm{p}=0.027)$, the source $\left(c^{2}=7.077, \mathrm{df}=2, \mathrm{p}=0.029\right)$ and the main utility $\left(c^{2}=8.057, \mathrm{df}=3, \mathrm{p}=\right.$ 0.045 ) of the camels. It was concluded that camels presented for slaughter at the Maiduguri abattoir have evidence of exposure to the RVF virus and may be means of transmission of the virus. Regular monitoring and control of transboundary animal movements were recommended in the study area.

\section{Introduction}

Rift Valley fever (RVF) is an emerging mosquito-borne zoonotic disease that threatens public health and animal agriculture in Africa and the Middle East. The causative agent, the RVF virus is listed as a select agent with significant potential for international spread and use in bioterrorism and has been responsible for widespread and devastating outbreaks of severe disease throughout Africa and the Arabian Peninsula (Bird et al., 2009). The agent is transmitted primarily by mosquitoes but could also be transmitted by direct contact with infected tissues and fluids (Leta et al., 2018; Linthicum et al., 2016). Epizootics and epidemics are usually recorded during years of exceptionally high rainfall. To date, RVF has been reported in over 30 countries in Africa in areas ranging from the dry, low-rainfall climate of Egypt, to the wet forest areas of Uganda and the Central African Republic, to the dry savanna lands of East and southern Africa. Some possible mechanisms for spread include migrating or windblown vectors, movements or importations of viraemic mammals, phoresy of RVFV-infected ticks on migratory birds, or movement of infected humans or vectors by aircraft (Linthicum et al., 2016). The epidemiology of the disease is very complex and involves multiple players that include mosquito, wild animals, domesticated livestock and humans (Bukbuk et al., 2014). Cattle, sheep, goats, and camels are particularly susceptible to RVF and serve as amplifying hosts for the virus (Linthicum et al., 2016). Epidemics of the disease are usually linked to persistent heavy rainfalls that favour the multiplication of its mosquito vectors (Linthicum et al., 2016). During the inter-epidemic period, the virus is primarily maintained by circulating at low levels among wildlife, livestock, and humans, transmitted by mosquito vectors (Kariuki Njenga and Bett, 2019). 
The one-humped camel, Camelus dromedarius, is an important pack and ride, dairy and meat animal in the semi-arid region of northeastern Nigeria (Jaji et al., 2017). They are usually kept for transportation; as a draft animal; as a source of hides, milk, and meat and for sport in some countries (Ishag and Ahmed, 2011). These activities bring them in close contact with human thus increased the chances to share infections. Most of the camels found in Nigeria were thought to have originated from eastern and northern Africa (Jaji et al., 2017) traverse through many countries on their way to the northeastern region of Nigeria. This may contribute to the spread of the RVF virus. A recent survey of domestic animals in the southwestern part of Nigeria indicated that the virus is actively circulating among domestic livestock in that region (Opayele et al., 2019). Similarly, a study from Borno state by Bukbuk et al., (2014) showed that RVF has comparatively the highest seroprevalence among the viral hemorrhagic fevers affecting humans in the State. However, there is a scarcity of published information on the disease in animals in the study area. Therefore, this study was conducted to determine the seroprevalence and investigate factors associated with exposure to the virus in camels slaughtered in Maiduguri abattoir, Borno state of Nigeria.

\section{Materials And Methods}

\section{Study Area}

The study was conducted at the Maiduguri abattoir located near the main livestock market within Maiduguri Metropolis. Maiduguri is the capital of Borno State, northeastern Nigeria. Maiduguri is located on latitude $11.8311^{\circ}$ north and longitude $13.1510^{\circ}$ east of the equator. It is the largest city in the northeastern part of Nigeria and covers a landmass of $132 \mathrm{~km}^{2}$. The city is situated at about 325 meters above sea level. According to the National Population Commission, the population of the city is estimated at 731,700 in 2015 with a projected population density of 5,543.2 inhabitants per $\mathrm{km}^{2}$. The main livestock market that supplies animals for slaughter is the abattoir and used to be the biggest livestock market in the northeastern part of the country. Presently, livestock trading especially that of cattle is currently suspended due to security reasons. The animals traded in the market are sourced from within the country and from Chad, Sudan, Cameroon and the Niger Republic. This makes it an important point for interaction between disease agents and their respective hosts.

Borno State is divided into two broad relief regions, namely the hilly mountainous which covers the south and southwestern parts of the state and the plains which dominate most of the central and northern parts of the state. The climate is semi-arid with about two climatic seasons that include the hot season with an average daily temperature of about $38.8^{\circ} \mathrm{C}$ and the cold season with an average daily temperature of about $36.8^{\circ} \mathrm{C}$. The two main vegetation zones are the Sudan savannah in the south and Sahel savannah in the north where Maiduguri is located.

\section{Study Design}


A cross-sectional study was designed to determine the prevalence and investigate the risk factors associated with the presence of antibodies to RVF Virus in camels slaughtered in Maiduguri abattoir. The study covered three sampling periods. The first period targeted when camel slaughter figure was at its highest around January-December, the second period when slaughter figure was moderate and the third period when the figure is at the lowest based on previous records of the abattoir. This was to enable us to obtain a fair representation of slaughter figures in the abattoir.

\section{Sample Size Determination}

The unit of analysis considered in the study was an individual animal. The sample size of the crosssectional study was calculated using the software, Statulator ${ }^{\odot}$ Statistical Program (Dhand and Khatkar, 2014). The earlier reported prevalence of $3.3 \%$ in camels (Olaleye, et al., 1996) was utilized as the expected proportion. The statistical power of $80 \%$ was assumed and alpha (a) level, precision or margin of error was considered at 0.05 . Based on the above assumptions, a minimum sample size of 45 camels was therefore required.

Alternatively, the same sample size was obtained using the formula for cross-sectional study (Thrusfield, 2007):

$$
n=\frac{z^{2} p(1-p)}{d^{2}}
$$

Where

$\mathrm{n}=$ sample size

$z=$ statistic for the level of confidence $(95 \% \mathrm{Cl})$

$\mathrm{P}=$ expected prevalence from previous study of $3.3 \%$ reported by Olaleye, et al., (1996)

$d=$ allowable error $(5 \%)$

After substituting the above parameters in the formular we have:

$$
n=\frac{(1.96)^{2} \times 0.03 \times(1-0.03)}{(0.05)^{2}}=45
$$

Therefore, a minimum of 45 serum samples was required for the study. However, the sample size was adjusted to 92 to increase the precision of the estimate of the prevalence rate.

\section{Inclusion Criteria}


Camels of all ages, both sexes, that were apparently healthy, whose demographic information are known and are presented for slaughter at the Maiduguri abattoir are eligible for inclusion into the study.

\section{Sample Collection and Handling}

The camels used in this study were sampled using convenience sampling. Sterile samples bottles were used for the collection of the blood samples after which the samples were handled according to standard procedure (Olaleye et al., 1996). The samples were allowed to clot at room temperature and transported to the laboratory in cold boxes with ice packs. The sera were separated from the clotted blood by centrifugation at $1,500 \mathrm{~g}$ for 10 minutes. The harvested sera were stored at $-20^{\circ} \mathrm{C}$ until tested.

\section{Camel Demographic Information Collection}

Camels presented for slaughtered that met the inclusion criteria were selected and included in the study. For every selected camel, the age, sex, source or origin, utility, body weights, body condition score and presence of post mortem lesion on the carcass were recorded. The age of camels in the study were determined using rostral dentition through the phenomenon of teeth eruption and wearing (Bello et al., 2013). To ease data analysis on age, the camels were categorized based on age. Camels that were five years and below were categorized as young while those above five years were categorized as adults. This because some camels attend sexual maturity at about five years of age (Rahim, 1997; Marai et al., 2009). The sex was determined by visual observation of the external genitalia.

The source and utility of the camels were determined through inquiry and interactions with owners or sellers. The body weights were estimated using body measurements that included chest girth, height at withers and hump girth (Boujenane, 2019). The body condition score was graded on a scale of 1 to 5 with a score of 5 being camel with an excellent body condition while a score of 1 is recorded for the camel with the worst body condition. This is because the body condition score is the external observable indicator health of the animal (Rahim, 1997; Islam et al., 2019). For each of the selected camels, a detailed post mortem examination was conducted on the carcass and the presence or absence of lesions were noted. The information collected above were cross-tabulated with the occurrence of antibodies for the determination of the associated risk factors.

\section{Serological Test}

The serological test used in the study was based on the principles described by Paweska et al., (2005). The test was performed using an Enzyme-Linked Immunosorbent Assay (ELISA) kit for detection of antiRVFV-Nucleoprotein antibodies by competitive ELISA from serum or plasma. The commercial kit used was the ID Screen ${ }^{\circledR}$ Rift Valley Fever Competition Multi-Species kit from Innovative Diagnostics, ID. Vet, France.

The test procedure was as described by the manufacturer and was as follows: 
A $50 \mu \mathrm{l}$ of the Dilution Buffer 19 was added to each of the 96 wells of the ELISA plate. Then, $50 \mu$ l of the

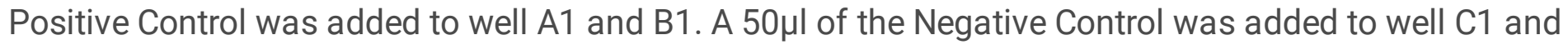
D1. Thereafter, $50 \mu$ l of each test samples were added to the remaining wells. The plate was incubated at $37^{\circ} \mathrm{C}$ for one hour. After the incubation, the wells were emptied and washed three times with $300 \mu \mathrm{l}$ of the Wash Solution avoiding drying of the wells between washings. An Anti-RVF-NP Conjugate $1 \mathrm{X}$ was prepared by diluting the Anti-RVF-NP-PO Conjugate $10 \mathrm{X}$ to $1 / 10$ the Dilution Buffer 19 . Thereafter, $100 \mu \mathrm{l}$ of Conjugate $1 \mathrm{X}$ was added to each of the wells. The plate was incubated for the second time at $21^{\circ} \mathrm{C}$ for 30 minutes. After the second incubation, the wells were emptied and washed three times with $300 \mu \mathrm{l}$ of the Wash Solution avoiding drying of the wells between washings. Thereafter, $100 \mu$ l of the Substrate Solution was added to each of the wells. The plate was incubated for the third time at $21^{\circ} \mathrm{C}$ for 15 minutes in the dark. Lastly, $100 \mu \mathrm{l}$ of the Stop Solution was added to each of the wells to stop the reaction. The optical densities of the test solutions were read and recorded at $450 \mathrm{~nm}$ using an ELISA reader.

The test was validated by calculating the mean value of the optical densities $\left(O D_{N C}\right)$ of the negative control and was found to be 1.2005 which greater than 0.7 . Similarly, the mean value of the optical densities of the positive control $\left(O D_{P C}\right)$ was found to be 0.08 which was less than 0.30 .

\section{Interpretation of the Result of the Test}

For each of the test samples, the competition percentage ( $\mathrm{S} / \mathrm{N} \%)$ was calculated as follows:

$$
S N \%=\frac{\text { Optical Density of sample }}{\text { Optical Density of Negative Control }} \times 100
$$

Samples presenting percentage competition of less than or equal to $40 \%$ were considered positive while those with greater than $40 \%$ were considered negative.

\section{Data Analysis}

The data generated from the study were managed and stored in a Microsoft Excel ${ }^{\circledR} 2011$ for Mac OS X (Microsoft Corporation) spreadsheet. The seroprevalence rates were calculated by dividing the number of seropositive samples by the total number of samples using EpiTools Epidemiological Calculators (Sergent, 2014). The differences between proportions of the categorical variables were tested using the Chi-squared test. The estimates and their respective confidence intervals were calculated at $95 \%$ level using Wilson (score) method described in a standard text (Brown et al., 2001). The mean values of the continuous variables were compared using an independent t-test. All the statistical analyses were performed using SPSS (version 23.0; SPSS Inc., Chicago, IL, USA) at the significance level of $a=0.05$.

\section{Results}




\section{Descriptive Statistics and Characteristics of Camels in the Study}

Out of the total 92 camels sampled in the study, 57 (62.0\%) were females while 35 (38.0\%) were males. For the age, the mean estimated age was 6.74 years with a standard deviation of 2.89 years. For the age categories, $29(31.5 \%)$ of the camels were categorized as young while $63(68.5 \%)$ were adults. The mean of the estimated live body weights was $331.85 \mathrm{~kg}$ with a standard deviation of $105.21 \mathrm{~kg}$. In terms of the sources/country of origin of the camels, 25 (27.5\%) camels were from Chad, 28 (30.4\%) from the Niger Republic and 39 (42.4\%) were sourced within Nigeria. For the body condition score, the average score for the camels in the study was 3.31 with a standard deviation of 0.88 . In terms of the presence of post mortem lesions, 67 (72.8\%) of the camels had visible post mortem lesions on their carcasses while 25 $(27.2 \%)$ did not have any. In terms of the main purpose of keeping/utility, $11(12.0 \%)$ were kept for the draft, 35 (38.0\%) for meat, 25 (27.2\%) for the milk and 21 (22.8\%) for transportation purposes. The distribution of all the sampled camels based on the serological test for antibodies to RVF virus showed that $19(20.7 \%)$ were positive while $73(79.3 \%)$ were negative.

\section{Seroprevalence of RVF in camels slaughtered in Maiduguri abattoir}

The prevalence of antibodies against the RVF virus in the study area based on the investigated risk factors is shown in Table 1 below. The overall prevalence of antibodies against RVFV in the study area was found to be $20.7 \%$ (95\% Confidence Interval, 13.6 - 30.0).

The Chi-squared test showed no significant difference based on sex $\left(c^{2}=0.015, d f=1, p=0.904\right)$ in terms of the presence of the antibodies to the RVF virus. The comparison based on age showed a significant difference between age and the presence of antibodies $\left(c^{2}=4.89\right.$, $\left.d f=1, p=0.027\right)$ in the camels. Similarly, the comparison based on sources/origin of camels showed a significant difference between source and $\left(c^{2}=7.077, d f=2, p=0.029\right)$ presence of antibodies. The test also showed no significant difference between the presence of antibodies and the occurrence of post mortem lesions on carcasses $\left(c^{2}=0.009, d f=1, p=0.925\right)$. For the main purpose of keeping the camel or its utility, the test showed a significant difference between the presence of antibodies and the main utility/purpose of keeping the camel $\left(c^{2}=8.057, d f=3, p=0.045\right)$.

Descriptive statistics and results of t-test analysis for the body weights and body condition score of the camels with positive and negative serological tests are shown in Table 2 below. The analysis showed no significant difference $(p>0.05)$ between the mean of the body weights of camels that tested positive and those that were negative. Similarly, there was no significant difference $(p>0.05)$ between the mean of the body condition scores of camels that tested positive and the mean for those that were negative. A Pearson correlation analysis showed a weak non-significant positive correlation $(r=0.153,95 \% \mathrm{Cl}$ 
$-0.053-0.347, p=0.144)$ between body weights and body condition scores of the camels sampled in this study. This means there is no significant relationship between the body weights and the body condition scores of the camels sampled in the study.

\section{Discussion}

The $20.7 \%$ seroprevalence reported in this study is observed to relatively higher than the $5.3 \%$ reported in livestock handlers (Opayele et al., 2018) and the 0.7\% (Opayele et al., 2019) among livestock slaughtered in Bodija Municipal abattoir in Ibadan, southwestern Nigeria. The observed disparity may be explained by the differences in species of animal sampled and the area studied. This is because camels may be at a higher risk of exposure to the virus due to their attributes of being transboundary animals that traverse borders thereby exposing them to higher risk (Faye, 2019). Moreover, the location of Maiduguri in northeastern Nigeria is considered to be closer to the hotspots of the disease in the north and east Africa (Arsevska et al., 2016; Lindahl et al., 2017) compared to lbadan, which is located in southwestern Nigeria which further away and considered to be at a lower risk. Similarly, the overall seroprevalence reported in this study was observed to be relatively higher when compared to the previously reported prevalence of 3.3\% by Olaleye et al., (1996) and the 3.13\% by Ezeifeka et al., (1982) in Kaduna and Sokoto states of Nigeria. The observed disparity may be due to changing dynamics in the population of camels and assay methodology used in the detection of antibodies against RVFV. This is because the earlier studies (Ezeifeka et al., 1982; Olaleye et al., 1996) used the haemagglutination-inhibition test while the present study used ELISA which is considered to be more sensitive.

The overall seroprevalence of $20.7 \%$ reported in this study was observed to be almost similar to the $19.9 \%$ reported in a recent study from the two northwestern states of Jigawa and Katsina in Nigeria (Musa et al., 2020). This may be because the two states share similar characteristics with Borno State since all the three states share international borders with other countries closer to the hotspots of the disease. In addition, the three states have similar climatic conditions thus exposed to similar risks of the disease (Caminade et al., 2011). The seroprevalence rate reported in camels in this study was also observed to be higher than the $14.1 \%$ reported in humans in Borno (Bukbuk et al., 2014) and this may suggest that camels have higher exposure rates than humans. The overall seroprevalence reported in this study is, however, observed to be lower than the $34 \%$ reported in Tunisia (Selmi et al., 2020). This may be due to the fact Tunisia is located in the hotspots of the disease and thus more favourable climatic conditions for the occurrence of the disease.

The analysis of the possible risk factors of the disease showed no statistically significant association between the presence of antibodies to the virus and the sex of the camels. This is in contrast with the previous report by Muturi et al., (2021) that reported a significant association between infection and sex of camel in Kenya. This disparity may be due to differences in climatic zones and husbandry practices in the two study areas. The study showed that age was a significant risk factor for the presence of antibodies and this agrees with previous reports from Kenya (Muturi et al., 2021) and Sudan (Abdallah et al., 2016). This may be because the older camels, having spent a long time in the environment might 
have been exposed to greater risk when compared to young (Abdallah et al., 2016; Selmi et al., 2020). The study showed that the source or locality of the camel was a significant risk factor for exposure to the virus and this also agrees with previous reports from Kenya (Muturi et al., 2021) and Sudan (Abdallah et al., 2016). This may be explained by the fact that RVF is a vector-borne disease that occurs in specific ecologies, meaning that camels from different locations have varying exposure rates to different factor influencing the occurrence of the disease (Ikegami and Makino, 2011). Finally, this study showed that the main utility of camel was a significant risk factor for the presence of antibodies. This is because camels are exposed to varying degrees of risks under different uses (El-Harrak et al., 2011; Napp et al., 2018).

The limitation of this is that the researchers relied on the retentive memories of the owners or sellers of the camels to collect data on the variables 'source/origin of the camels' and 'utility of the camels' with no other means to confirm the authenticity of the responses. This could be potential sources of recall bias.

It can be concluded from this study that camels presented for slaughter for human consumption at the Maiduguri abattoir have evidence of exposure to RVF virus and therefore constitute a risk to the abattoir personnel working, the general public and other livestock in the study area since they may serve as possible sources for transmission of the virus. The overall seroprevalence of the disease in the study area was $20.7 \%$ (95\% Confidence Interval, 13.6 - 30.0). It can also be concluded that the sex of camels and presence of post mortem lesion on their carcass were not significant risk factors for exposure to RVF virus while the age, source or origin of the camel and the main usage/utility of the camels were significant risk factors for exposure to the virus.

To reduce the risk of occurrence of the disease it is recommended that regular monitoring and control of transboundary animal movements be instituted in the study area in addition to carrying out public enlightenment on the dangers of the disease. Further research is needed in the study area to identify the possible sources of infection with the virus in the study area. There is also a need to conduct further research to determine the role of camels in the transmission of the RVF virus to other livestock species and humans in the study area. This information will be useful for designing more effective surveillance systems and intervention measures against the disease.

\section{Declarations}

\section{Ethics approval}

This is an observational study. The University of Maiduguri, Faculty of Veterinary Medicine Animal Use and Ethics Committee has confirmed that no ethical approval is required.

\section{Availability of data and materials}

The datasets used and analysed in this study are available from the corresponding author on request.

\section{Conflicts of interests}


The authors have no conflicts of interest to declare that are relevant to the content of this article.

\section{Funding}

No funding was received for conducting this study.

\section{Authors' contributions}

Conceptualization: [Hassan Ismail Musa, Muhammad Mamman Gashua]; Methodology: [Hassan Ismail Musa, Mohammed Sani, Muhammad Mamman Gashua]; Formal analysis and investigation: [Hassan Ismail Musa, Abubakar Sadiq Muhammad]; Writing - original draft preparation: [Hassan Ismail Musa, Muhammad Mamman Gashua]; Writing - review and editing: [Hassan Ismail Musa, Abdulyeken Olawale Tijjani, Saleh Mohammed Jajere, Shuaibu Gidado Adamu, Adamu Saleh Saidu]; Supervision: [Caleb Ayuba Kudi]

\section{Acknowledgements}

we acknowledge the contributions of Malam Yahuza Suleiman Maitala of the Viral Zoonoses Laboratory, Department of Veterinary Public Health and Preventive Medicine, Ahmadu Bello University, Zaria and Mr John Madu of the Virology Laboratory, Department of Veterinary Microbiology, the University of Maiduguri for their technical support. Our since thank to Dr Bello Gaji of the Maiduguri abattoir for his assistance and support during the sample collection.

\section{References}

Abdallah, M.M.M., Adam, I.A., Abdalla, T.M., Abdelaziz, S.A., Ahmed, M.E. and Aradaib, I.E., 2016. A survey of rift valley fever and associated risk factors among the one-humped camel (Camelus dromedaries) in Sudan Irish Veterinary Journal, 69, 1-6 (Irish Veterinary Journal)

Arsevska, E., Hellal, J., Mejri, S., Hammami, S., Marianneau, P., Calavas, D. and Hénaux, V., 2016. Identifying areas suitable for the occurrence of Rift Valley fever in North Africa: implications for surveillance Transboundary and emerging diseases, 63, 658-674 (Wiley Online Library)

Bello, A., Sonfada, M.L., Umar, A.A., Umaru, M.A., Shehu, S.A., Hena, S.A., Onu, J.E. and Fatima, O.O., 2013. Age estimation of camel in Nigeria using rostral dentition Scientific Journal of Animal Science, 2, 9-14 (Scientific Journal of Animal Science)

Bird, B.H., Ksiazek, T.G., Nichol, S.T. and MacLachlan, N.J., 2009. Zoonosis Update Rift Valley fever virus Journal of the American Veterinary Medical Association, 234, 883-93

Boujenane, l., 2019. Comparison of body weight estimation equations for camels (Camelus dromedarius) Tropical Animal Health and Production, 51, 1003-1007 
Brown, L.D., Cai, T.T. and DasGupta, A., 2001. Interval estimation for a binomial proportion Statistical Science, 101-117

Bukbuk, D.N., Fukushi, S., Tani, Hideki and Yoshikawa, T., 2014. Development and validation of serological assays for viral hemorrhagic fevers and determination of the prevalence of Rift Valley fever in Borno State, Nigeria Transaction of the Royal Society of Tropical Medicine and Hygiene, 25, 289-313

Bukbuk, D.N., Fukushi, S., Tani, H., Yoshikawa, T., Taniguchi, S., Iha, K., Fukuma, A., Shimojima, M., Morikawa, S., Saijo, M., Kasolo, F. and Baba, S.S., 2014. Development and validation of serological assays for viral hemorrhagic fevers and determination of the prevalence of rift valley fever in Borno State, Nigeria Transactions of the Royal Society of Tropical Medicine and Hygiene, 108, 768-773 (Narnia)

Caminade, C., Ndione, J.-A., Kebe, C.M.F., Jones, A.E., Danuor, S., Tay, S., Tourre, Y.M., Lacaux, J., Vignolles, C. and Duchemin, J.B., 2011. Mapping Rift Valley fever and malaria risk over West Africa using climatic indicators Atmospheric Science Letters, 12, 96-103 (Wiley Online Library)

Dhand, N.K. and Khatkar, M.S., 2014. Statulator Statistical Program

El-Harrak, M., Martín-Folgar, R., Llorente, F., Fernández-Pacheco, P., Brun, A., Figuerola, J. and JiménezClavero, M.Á., 2011. Rift Valley and West Nile virus antibodies in camels, north Africa Emerging infectious diseases, 17, 2372 (Centers for Disease Control and Prevention)

Ezeifeka, G.O., Umoh, J.U., Belino, E.D. and Ezeokoli, C.D., 1982. A serological survey for Rift Valley fever antibody in food animals in Kaduna and Sokoto States of Nigeria International journal of zoonoses, 9 , $147-151$

Faye, B., 2019. TADs in the Dromedary In:, Transboundary Animal Diseases in Sahelian Africa and Connected Regions, (Springer), 91-103

Ikegami, T. and Makino, S., 2011. The pathogenesis of Rift Valley fever Viruses, 3, 493-519 (Molecular Diversity Preservation International)

Ishag, I.A. and Ahmed, M.K.A., 2011. Characterization of production system of Sudanese camel breeds Livestock Research for Rural Development, 23

Islam, S., Ferdous, J., Rahman, M.K., Akter, S., Hassan, M.M. and Islam, A., 2019. Reference values for hematological and serum biochemical parameters of dromedary camel (Camelus dromedarius) in subtropical climate of Bangladesh Adv. Anim. Vet. Sci, 7, 232-237

Jaji, A.Z., Elelu, N., Mahre, M.B., Jaji, K., Mohammed, L.I.G., Audu Likita, M., Kigir, E.S., Onwuama, K.T. and Saidu, A.S., 2017. Herd growth parameters and constraints of camel rearing in Northeastern Nigeria Pastoralism, 7 (Pastoralism) 
Kariuki Njenga, M. and Bett, B., 2019. Rift Valley Fever Virus-How and Where Virus Is Maintained During Inter-epidemic Periods Current Clinical Microbiology Reports, 6, 18-24 (Current Clinical Microbiology Reports)

Leta, S., Beyene, T.J., De Clercq, E.M., Amenu, K., Kraemer, M.U.G. and Revie, C.W., 2018. Global risk mapping for major diseases transmitted by Aedes aegypti and Aedes albopictus International Journal of Infectious Diseases, 67, 25-35 (International Society for Infectious Diseases)

Lindahl, J., Bett, B., Robinson, T. and Grace, D., 2017. Rift valley fever and the changing environment: a case study in East Africa In:, Examining the Role of Environmental Change on Emerging Infectious Diseases and Pandemics, (IGI Global), 178-204

Linthicum, K.J., Britch, S.C. and Anyamba, A., 2016. Rift Valley Fever: An Emerging Mosquito-Borne Disease Annual Review of Entomology, 61, 395-415

Marai, I.F.M., Zeidan, A.E.B., Abdel-Samee, A.M., Abizaid, A. and Fadiel, A., 2009. Camel's reproductive and physiological performance traits as affected by environmental conditions Tropical and Subtropical Agroecosystems, 10, 129-149 (Universidad Autónoma de Yucatán)

Musa, A.A., Ayo, Y.S., Lushakyaa, A., Anthony, S., Bida, A.N., Sikiti, G.B., Salamatu, M.-M., Daniel, N.W., Idoko, I.S. and Emmanuel, B.O., 2020. Serological evidence of Rift Valley fever infection and risk factors among one-humped camels (Camelus dromedarius) in Northern Nigeria bioRxiv (Cold Spring Harbor Laboratory)

Muturi, M., Akoko, J., Nthiwa, D., Chege, B., Nyamota, R., Mutiiria, M., Maina, J., Thumbi, S.M., Nyamai, M. and Kahariri, S., 2021. Serological evidence of single and mixed infections of Rift Valley fever virus, Brucella spp. and Coxiella burnetii in dromedary camels in Kenya PLoS neglected tropical diseases, 15, e0009275 (Public Library of Science San Francisco, CA USA)

Napp, S., Chevalier, V., Busquets, N., Calistri, P., Casal, J., Attia, M., Elbassal, R., Hosni, H., Farrag, H. and Hassan, N., 2018. Understanding the legal trade of cattle and camels and the derived risk of Rift Valley Fever introduction into and transmission within Egypt PLoS neglected tropical diseases, 12, e0006143 (Public Library of Science)

Olaleye, O.D., Tomori, O., Lapido, M.A. and Schmitz, H., 1996. Rift Valley fever in Nigeria: infections in humans Revue Scientifique et Technique de I'OIE, 15, 923-935

Olaleye, O.D., Tomori, O. and Schmitz, H., 1996. Rift Valley fever in Nigeria: infections in domestic animals Revue Scientifique et Technique de l'OIE, 15, 937-946

Opayele, A.V., Ndiana, L.A., Odaibo, G.N. and Olaleye, D.O., 2019. Serological evidence of Rift Valley fever virus infection in slaughtered ruminants in Nigeria Journal of Immunoassay and Immunochemistry, 40, 367-377 (Taylor \& Francis) 
Opayele, A. V, Odaibo, G.N. and Olaleye, O.D., 2018. Rift valley fever virus infection among livestock handlers in Ibadan, Nigeria Journal of Immunoassay and Immunochemistry, 39, 609-621 (Taylor \& Francis)

Paweska, J.T., Mortimer, E., Leman, P.A. and Swanepoel, R., 2005. An inhibition enzyme-linked immunosorbent assay for the detection of antibody to Rift Valley fever virus in humans, domestic and wild ruminants Journal of Virological Methods, doi: 10.1016/j.jviromet.2005.02.008

Rahim, S.E.A.A., 1997. Studies on the age of puberty of male camels (Camelus dromedarius) in Saudi Arabia The veterinary journal, 154, 79-83 (Elsevier)

Selmi, R., Mamlouk, A., Said, M. Ben, Yahia, H. Ben, Abdelaali, H., Chehida, F. Ben, Daaloul-Jedidi, M., Gritli, A. and Messadi, L., 2020. First serological evidence of the Rift Valley fever Phlebovirus in Tunisian camels Acta tropica, 207, 105462 (Elsevier)

Sergent E. S. G., 2014. EpiTools - Calculate confidence limits for a sample proportion

Thrusfield, M., 2007. Veterinary epidemiology, Third Edit (John Wiley \& Sons: Oxford UK)

\section{Tables}

Table 1: Prevalence and univariate Chi-squared tests of risk factors of the presence of antibodies against Rift Valley Fever (RVF) virus among Camels Slaughtered in Maiduguri Abattoir, Borno State, Nigeria 


\begin{tabular}{|c|c|c|c|c|c|c|}
\hline Variable & Categories & $\begin{array}{l}\text { Total } \\
\text { examined }\end{array}$ & $\begin{array}{l}\text { Number } \\
\text { Positive }\end{array}$ & $\begin{array}{l}\text { Prev. } \\
\text { (\%) }\end{array}$ & $\begin{array}{l}95 \% \mathrm{Cl} \text { of } \\
\text { Prevalence }\end{array}$ & $\begin{array}{l}\mathrm{p}- \\
\text { value }\end{array}$ \\
\hline \multirow[t]{2}{*}{ Sex } & Female & 57 & 12 & 21.1 & $12.5-33.3$ & 0.904 \\
\hline & Male & 35 & 7 & 20.0 & $10.0-35.9$ & \\
\hline \multirow[t]{2}{*}{ Age } & Young & 29 & 2 & 6.9 & 2.9- 22.0 & $0.027 *$ \\
\hline & Adult & 63 & 17 & 27.0 & $17.6-39.0$ & \\
\hline \multirow[t]{3}{*}{ Source/Origin } & Chad & 25 & 7 & 28.0 & $14.3-47.6$ & $0.029 *$ \\
\hline & Niger & 28 & 9 & 32.1 & $17.9-50.7$ & \\
\hline & Nigeria & 39 & 3 & 7.7 & $2.7-20.3$ & \\
\hline \multirow{2}{*}{$\begin{array}{l}\text { PM Lesion } \\
\text { Present }\end{array}$} & No & 67 & 14 & 20.9 & $12.9-32.1$ & 0.925 \\
\hline & Yes & 25 & 5 & 20.0 & $8.9-39.1$ & \\
\hline \multirow[t]{4}{*}{ Main Usage } & Draft & 11 & 5 & 45.5 & $21.3-72.0$ & $0.045^{\star}$ \\
\hline & Meat & 35 & 3 & 8.6 & $3.0-22.4$ & \\
\hline & Milk & 25 & 5 & 20.0 & $8.9-39.1$ & \\
\hline & Transport & 21 & 6 & 28.6 & $13.8-50.0$ & \\
\hline
\end{tabular}

*=significantly different, $\mathbf{C l = c o n f i d e n c e ~ i n t e r v a l , ~ P r e v = P r e v a l e n c e ~}$

Table 2: Descriptive statistics and t-test analysis of camels with positive and negative antibodies against RVF virus
Variable
Descriptive
positive $(n=19)$
Negative $(n=73)$
p-value

\begin{tabular}{lllllllll} 
& Range & Mean & SD & Mean & SEM & Mean & SEM & \\
\hline Body Weight & 350.0 & 331.8 & 105.2 & 292.1 & 22.7 & 342.2 & 12.3 & 0.064 \\
\hline Body Condition Score & 3.0 & 3.32 & 0.88 & 3.3 & 0.25 & 3.3 & 0.15 & 0.773
\end{tabular}

*=significantly different, $\mathrm{SD}=$ standard deviation, $\mathrm{SEM}=$ standard error of the mean 